\title{
APPLICATION OF GEOGRAPHIC INFORMATION SYSTEMS (GIS) IN ANALYSIS OF GEOLOGICAL RISK FACTORS AND ASSESSMENT OF GEOHAZARDS IN DAUGAVPILS AND ILŪKSTE DISTRICTS
}

\author{
Juris Soms, Kaspars Laizāns \\ Daugavpils University, Faculty of Nature Sciences and Mathematics, \\ Parādes st.1, Daugavpils, LV 5401, Latvia \\ Ph.: +371 29295432, e-pasts: juris.soms@du.lv; kaspars.laizans@inbox.lv
}

\begin{abstract}
This article deals with the main aspects of geological and geomorphological hazards (geohazards) assessment by presenting review of GIS-based methodology for identification and analysis of environmental hazards of such type to which the Daugavpils and Ilükste districts are exposed. It includes (1) critical review of the availability and state of the art in data sources about geological risk factors, (2) a description of using geomatics methods for obtaining thematic layers of risk factors and techniques of their combining and overlaying, and (3) an analysis and assessment of summary geohazard risk. Such a complex GIS-based studying of geohazards has not been performed before in the territory under study, nor has it been attempted in Latvia. At the same time obtained results allow highlighting areas exposed to geological risk within the Daugavpils and Ilükste districts, hence providing relevant information for spatial planning of these territories.
\end{abstract}

Keywords: Geographical Information System, geohazard assessment, geological risk factors.

\section{Introduction}

The analysis and identification of natural geological and geomorphological hazards (geohazards) associated with natural processes is of topical interest to the scientific community and at the same time adequate assessment of such risk is very important for authorities dealing with territorial planning [1]. Hence analysis of geological risk factors and assessment of potential hazards related to these factors is one of the prerequisites in terms of rational management and sustainable using of territories in the world [2, 3, 4]. Despite the fact, that unlike some of European countries, Latvia rarely suffers from natural hazards, such as damaging earthquakes or floods of high magnitude, though information about potential geohazards is very important to assist decision-making in spatial planning and designing of land use in our country too [5]. Obtaining of such information on the one hand allows to mitigate the risks and threats caused by possible occurring of endogenic or exogenic geological processes or natural disasters like floods, which endanger buildings, objects of infrastructure and people; and on the other hand information about geohazards is important considering the demands of EU legislation documents in the field of environmental management and territorial planning [6, 7]. Thereby, in order to ensure planning of development and management of territories at municipal level in Latvia, and simultaneously to prevent risks associated with geological or geomorphological hazards, it is necessary to aggregate geological information and to develop unified methodology allowing to assess the geological risk.

In recent years, a different approaches has been used in assessment of the risk of geohazards in Latvia, e.g. mapping of selected risk factors and preparing analogue geological maps, cartographic analysis and overlaying methods. However, there are little studies on the integration of geological and geomorphological risk factors in Geographic Information Systems (GIS) to identify the areas susceptible to geohazards in Latvia, though adequate and timely GIS-based assessing the expected consequences of geomorphic processes and hazards is the goal of many international research works. Review of literature dealing with the issues of geohazards and applications for multicriteria evaluation of geological risk factors $[8,9,10]$, 
reveals that during the past two decades in many countries GIS-based methods became the main tool for effective risk assessment purposes. This tendency is determined, first of all, by the geospatial character of data describing factors of geological and geomorphological risk, hence allowing to transform them into GIS data, and secondly, by possibility to integrate such data that handle spatial information about geographic distribution of risk factors in GIS and to use this software tools for multicriteria geospatial analysis. Considering that, authors worked out GIS-based methodology adopted for physiogeographic and geological conditions of Latvia, which allows to estimate the potential geohazards risk at local scale as well as for the whole territory of each municipality. Such a complex GIS-based studying of geohazards has not been performed before in the territory under study, nor has it been attempted in our country.

\section{Materials and methods}

Research and developing of methodology presented in this paper had been carried out by using of tools of ArcGIS software, as well as by other means and techniques of geomatics. In addition aggregation and analysis of the information, and field survey was carried out in order to obtain necessary input data or to verify results of the research.

First of all, factors of geological and geomorphological risk which potentially can affect the Daugavpils and Ilūkste districts were identified. Review of scientific publications and special literature dealing with issues of geological and geomorphological risk $[11,12,2]$ reveals, that commonly a term "geohazard" includes great diversity of different processes, however, as the major categories are mentioned geological hazards, like mass movements or karst processes, hydrometeorological and fluvial hazards like floods and river channel changes, geomorphological hazards like accelerated soil erosion by water and geophysical hazards like earthquakes or volcanoes. The more general definition given by Zelčs and Markots [5] describes geological risk as probability that exogenic or endogenic geological processes can cause or human activities can enable the negative impact of these processes on environment, human life, health or property, as well as potential consequences of such undesirable processes which pose risk for a certain time period. Considering this definition and content of term "geohazard", as well as geographic location of territory under study, its physiogeographic features and geological structure, the following geological and geomorphological risk factors potentially exposing the territories of the Daugavpils and Ilūkste districts to geohazards were identified: flood hazard, seismic hazard, karst hazard, wind erosion and aeolian processes hazard, landslide and soil erosion geomorphological hazard, coastal erosion hazard.

Thereafter desk-based studies, aggregating and analysing of the data about the geographic distribution of these hazards were carried out. For this purposes search through the internet resources of responsible institutions like planning departments of municipalities, as well as examination of reports of field studies, expeditions, and analogue geological maps [13] available in the Geological Fund of the Latvian Environment, Geology and Meteorology Centre had been done. Information about location of tectonic faults and historical records of earthquakes was obtained on the basis of published information sources [14, 15]. The obtained information allows to get understanding about the state of the art in data sources of geological risk factors and to locate areas of each risk factor for further GIS-based studies.

GIS tools and other means and techniques of geomatics were used for digitizing and preparation of thematic layers of raster and vector formats, converting and integrating GPS data into GIS, creating digital elevation model of the Daugavpils and Ilūkste districts and preparing of maps. Geospatial data of discrete type were represented as polygons (e.g. areas potentially affected by floods, karst, wind erosion, coastal erosion) or polylines (tectonic faults and zones of historically recorded earthquakes) of *.shp format. Geospatial data of 
continuous type (e.g. risk of landslides and accelerated soil erosion by water) were represented as ESRI Grid raster with pixel size $10 \times 10 \mathrm{~m}$. For deriving these raster data the digital elevation model was prepared, which in turn were created from digitized contour lines by tool Topo to Raster. For this purpose contour lines in topographic maps (coordinate system CK-42) at scale 1:10,000 and elevation interval of $2 \mathrm{~m}$ was digitised by applying the standard procedure.

Considering a range and large space of territories affected by flooding, traditional methods, e.g. conventional topographic survey or GPS mapping, cannot be used for identification of inundated areas. For these purpose geomatic methods as using of remote sensing and GIS was chosen as the most appropriate. On the basis of hydrological data about mean and maximal flood level altitudes, standard procedure of interpolation and derived contour lines construction from points of known elevation and local topography indicated in maps was performed. Vector polygons representing inundated territories at different flood level were created by geospatial analysis and digitizing GIS data layers from topographical maps (scale 1:10 000 with contour interval $1 \mathrm{~m}$ ) using ArcGIS software. Computed inundated territories shape conformity to real situation was validated by comparing ones with remotely sensed data, field survey GPS, and oblique aerial photography. The first of tasks, i.e. processing of remote sensing data, was carried out by use of LANDAST false-colour image of territory under study taken during spring floods in 1979 (Fig 1.). Situation fixed in this image illustrates dimension of inundation triggered by mean annual flood level. The second and third of tasks were performed during the floods in 2010, when conformity of digitised flooded territory was verified in situ by Real Time Kinematic GPS LEICA GX 12302 GG and simultaneously by oblique aerial photography taken from motorised delta-glider.

Comparison of computed inundated territory by means of GIS with remotely sensed image, data of high accuracy GPS field survey and oblique aerial photos indicates that obtained data layers confirm to real situation and well delineates the flood hazards polygon.

After the preparing of geospatial GIS data representing each factor of geological risk, vector data were converted into regular raster layers in order to range them and combine into one summary layer of geohazards. It estimates total geological risk in each pixel from data, collected by a combination of GIS mapping techniques, physical GPS survey and remote sensing (LANDSAT images and oblique aerial photography) on the six elements of risk. The individual relative value of each factor of geological risk was estimated according to approved methodology [2], which arranging the risk factors in order of increasing of possible loss and the probability for an individual hazard event. Subsequently, it allows to range risk factors and to evaluate its relative contribution to total risk (Table 1.).

Table 1.

Relative values of geological risk factors in diminishing sequence

\begin{tabular}{|l|c|}
\hline \multicolumn{1}{|c|}{ Geological hazard factor (and abbreviation ) } & $\begin{array}{c}\text { Individual relative } \\
\text { value } \\
\text { (dimensionless) }\end{array}$ \\
\hline Flood hazard (FL) & 6 \\
\hline Seismic hazard (SE) & 5 \\
\hline Karst hazard (KA) & 4 \\
\hline Wind erosion and aeolian processes hazard (AE) & 3 \\
\hline $\begin{array}{l}\text { Landslide and soil erosion geomorphological erosion hazard } \\
\text { (LS) }\end{array}$ & 2 \\
\hline Coastal erosion hazard (CO) & 1 \\
\hline
\end{tabular}




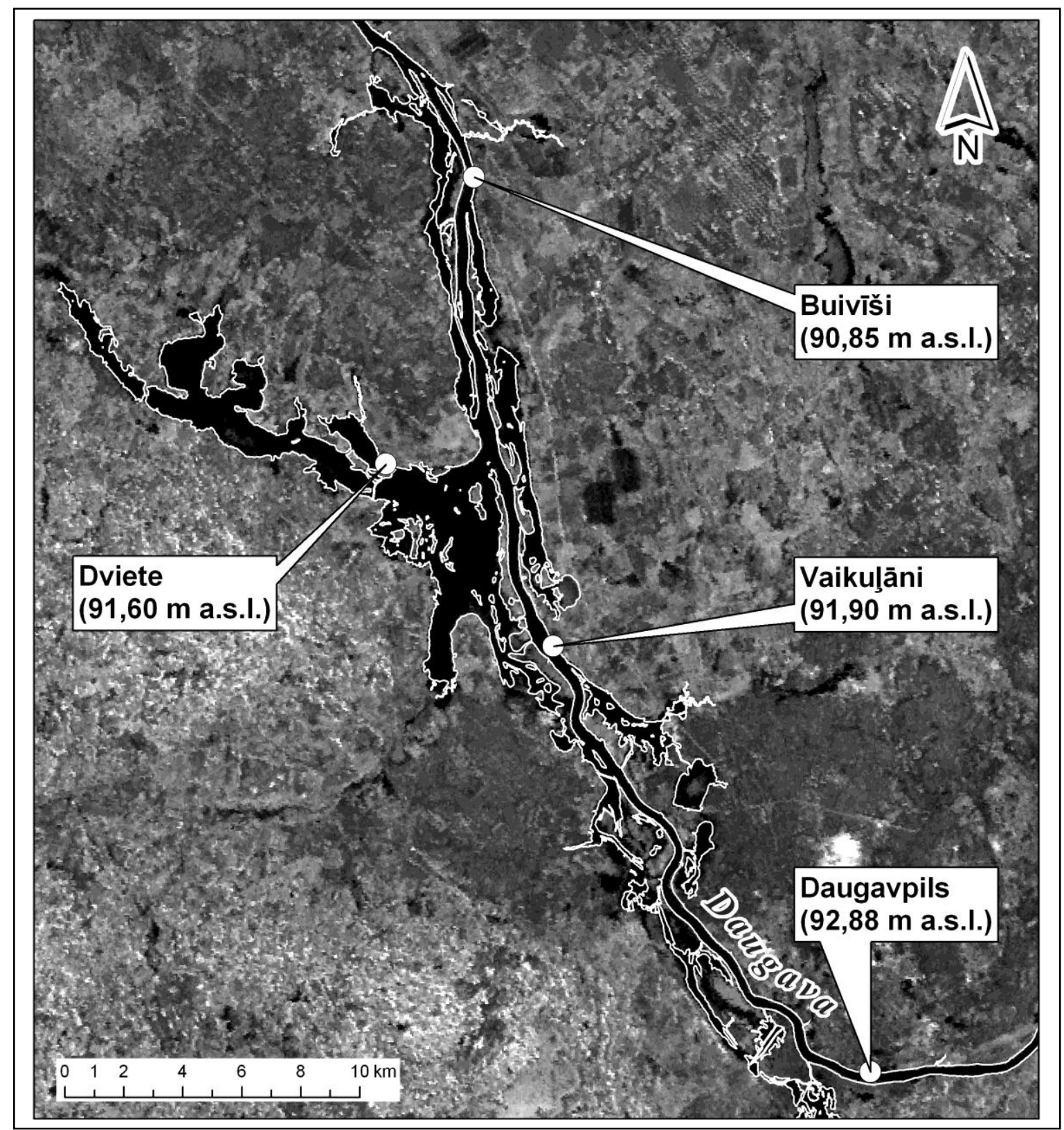

Fig. 1. Comparison of really inundated territory (LANDSAT raster image in background, flooded territory is coloured in black due to near-zero reflectance in IR band on false colour image) with GIS-computed (white lines). Circles represent hydrological stations and their name. Figures in callouts indicate flood levels recorded at these hydrological stations at the same date when satellite image was taken

The operation of combining of separate risk factors into summary layer was performed by ArcGIS extension Spatial Analyst, by tool Raster Calculator according to Map Algebra syntax expression (1):

$$
\mathrm{SUM}_{\text {hazard }}=\mathrm{FL}+\mathrm{SE}+\mathrm{KA}+\mathrm{AE}+\mathrm{LS}+\mathrm{CO}
$$

Finally, the data obtained during geospatial analysis and thematic layers were aggregated in the map of geological risk, which can be used for purposes of territorial planning of the Daugavpils and Ilūkste districts. 


\section{Results and discussion}

Obtained results, first of all, show that information and data about geological risk factors within the Daugavpils and Ilūkste districts is fragmented, not enough systematised and is available only in analogue format (printouts and maps). In additional it is necessary to point out that there is no geohazards data in digital format, and for user it is not possible to obtain this information via internet. Moreover, the degree of detailed elaboration considering the scale of maps does not allow using them for purposes of spatial and territorial planning at municipal or local level. Summarising aforementioned it necessary to remark that state of the art in data sources stored in the Geological Fund of the Latvian Environment, Geology and Meteorology Centre actually is beneath contempt in context of urgent necessity of GIS-based analysis of nature hazards and decision support for hazard mitigation.

The results of integration and geospatial data reveal, that considerable part of the territory of the Daugavpils and Ilūkste districts are exposed to the risk of mass movement processes, mainly landsliding formation, and to the risk of accelerated soil erosion by water. In particular the steep slopes within the Latgale upland, Augšzeme upland and the largest river valleys potentially are exposed to the geomorphological risk (Fig 2.). The lower values of geological risk are associated with coastal processes and wind erosion and aeolian processes hazard. The coastal processes affect very narrow zones along the littorals of the largest lakes, e.g. the Lake Sventes, the Lake Riču etc. The aeolian processes can become activate within the area of inland dunes in central part of the Daugavpils district, though this area at the present is afforested and possible risk relates only to the case of total forest clearance.

However, the highest degree of geological risk is associated with flooding, because during the floods of high levels and high magnitude (period of recurrence 1 or 5 times par $100 \mathrm{y}$ ), to the risk of inundation are exposed from $20 \%$ to $40 \%$ of territory of local rural municipalities, e.g. Dviete local municipality. Simultaneously, high degree of geohazards is associated with seismotectonic processes, which geographically are located in form of wide zone orientated from north-west to south-east. This zone encompasses large areas of both the Daugavpils and Ilūkste districts, and within it historically were recorded earthquakes of 4.7 magnitude according to Richter's scale. In combination with risk related to presence of objects of infrastructure with potential threats to environment, e.g. oil products and gas pipelines, waste dumps, gasoline stations and depositories, railway lines, this factor of geological risk determines relatively high degree of geohazards in both municipalities. 


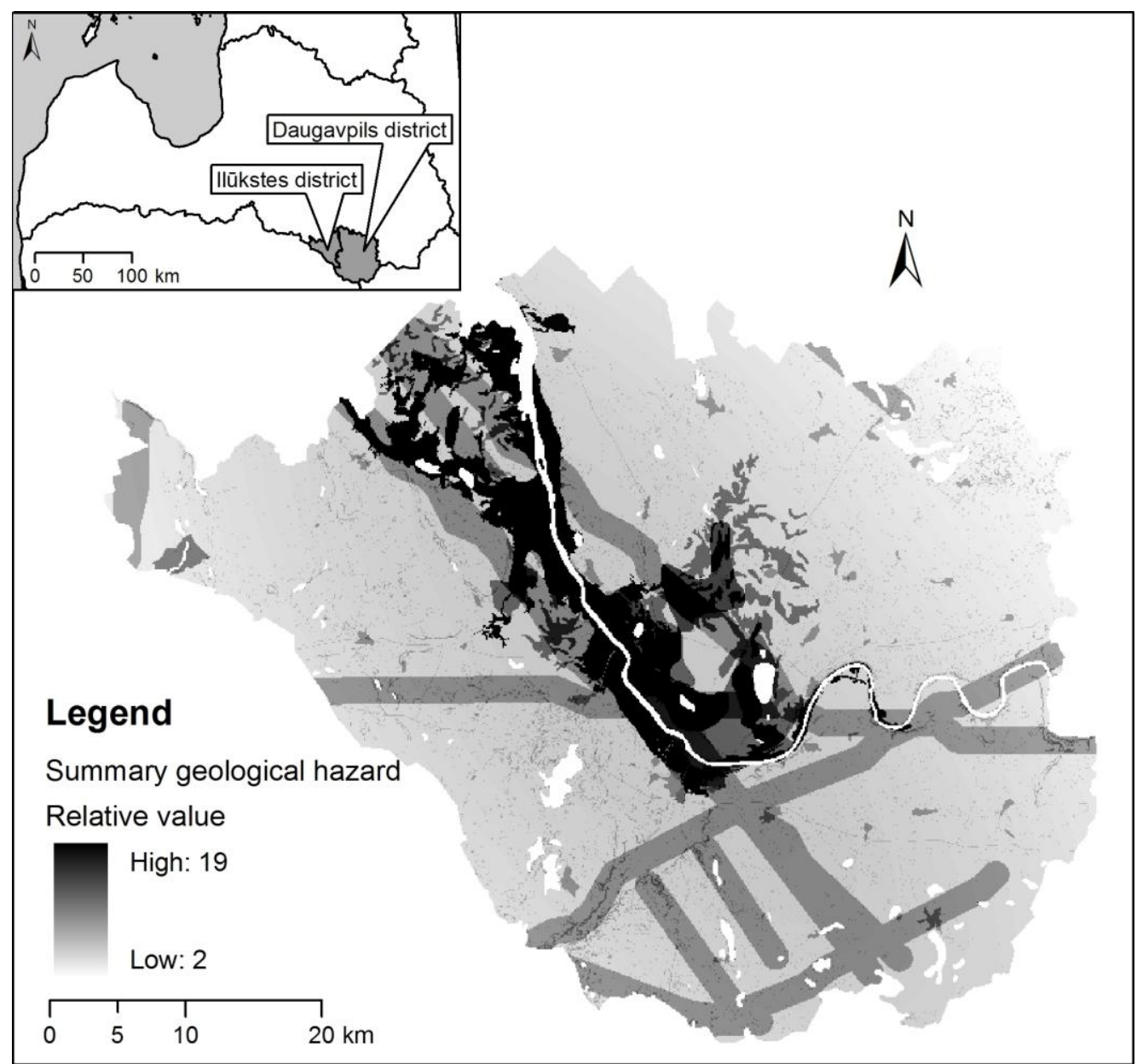

Fig. 2. The map of summary geological hazard within the Daugavpils and Ilūkste districts

\section{Conclusions}

The results of the given research based on GIS analysis of geological risk factors and assessment of geohazards demonstrates, that highest risk of geohazards in the Daugavpils and Ilūkste districts is associated with floods of high magnitude, because this natural disaster potentially can affect more than $20 \%$ of territory in some local municipalities, thus determining high possible economical losses and negative impact on environment.

The seismotectonic risk associated with possible earthquakes exceeding a 4.0 magnitude according to Richter's scale is among those principal geological risk factors which in combination with the technogenic risk can harmfully affect the infrastructure and environment in large areas in the Daugavpils and Ilūkste districts.

The second-grade geological risk factors are coastal processes, wind erosion and aeolian processes hazards, due to small scale of expression as well as presence of protective cover of forest vegetation in the areas potentially exposed to hazards of these exogenic geological processes.

Despite the fact that geomorphological hazards like mass movement processes and soil erosion by water potentially can affect large areas, at the present moment this factors are impeded by presence of natural vegetation cover. Considering the potential risk of landsliding and linear erosion, several territories in the Daugavpils and Ilūkste districts should be afforested to prevent reactivation of these processes.

Application of GIS software and means of geomatics allow to assess very effectively geohazards and potential geological risk, thus enabling wide opportunities for using of these 
digital data in form of electronic tables or GIS maps by governmental municipal and private institutions for purposes of spatial and territorial planning. Simultaneously digital format of information depicting geographic distribution of geological risk makes it accessible to society via internet.

\section{Acknowledgment}

Research reported in this article was supported by the ESF project No. 2009/0151/1DP/1.1.2.1.1/09/IPIA/VIAA/012 “Support of master's studies in Daugavpils University"

\section{References}

1. Campus, S., Barbero, S., Bovo, S., Forlati, F. Evaluation and Prevention of Natural Risks. Taylor \& Francis, UK, 2007, 470 pp.

2. Smith, K., Petley, D.N. Environmental Hazards: Assessing Risk and Reducing Disaster. $5^{\text {th }}$ edit. Routledge, New York, USA, 2009, 416 pp.

3. Crozier, M., Glade, T. Hazard assessment for risk analysis and risk management. In: Alcántara-Ayala I., Goudie A. (eds.), Geomorphological Hazards and Disaster Prevention. Cambridge Univ. Press, Cambridge, UK, 2010, pp.221-232.

4. Higgitt, D. Geomorphological hazards and sustainable development. In: Alcántara-Ayala I., Goudie A. (eds.), Geomorphological Hazards and Disaster Prevention. Cambridge Univ. Press, Cambridge, UK, 2010, pp.257-268.

5. Zelčs, V., Markots, A. Ģeologiiskās informācijas izmantošana teritorijas attīstības plānošanā. Valsts ǵeoloǵijas dienests, Latvijas Universitāte, Rīga, 1999, 123 lpp.

6. Directive 2000/60/EC of the European Parliament and of the Council of 23 October 2000 establishing a framework for Community action in the field of water policy (Water Framework Directive). Official Journal of the European Communities, 2000. L 327, vol. 43, 22 December 2000, pp. 1- 72.

7. Directive 2007/60/EC of the European Parliament and of the Council of 23 October 2007 on the assessment and management of flood risks (Floods Directive). Official Journal of the European Union, 2007. L 288, vol. 50, 6 November 2007, pp. $27-34$.

8. Chen K., Blong R., Jacobson C. MCE-RISK: integrating multicriteria evaluation and GIS for risk decisionmaking in natural hazards. Environmental Modelling \& Software, 16 (4), 2001, pp. 387-397.

9. Fedeski, M., Gwilliam, J. Urban sustainability in the presence of flood and geological hazards: The development of a GIS-based vulnerability and risk assessment methodology. Landscape and Urban Planning, 83 (1), 2007, pp.50-61.

10. Van Westen, C.J. GIS for the assessment of risk from geomorphological hazards. In: Alcántara-Ayala I., Goudie A. (eds.), Geomorphological Hazards and Disaster Prevention. Cambridge Univ. Press, Cambridge, UK, 2010, pp.205-220.

11. Glossary of Environment Statistics: Studies in Methods. Series F, No. 67, United Nations, New York, 1997, $78 \mathrm{pp}$.

12. Landesman, Y.L. Public health management of disasters: The practice guide. American Public Health Association, NW, Washington, DC,2001, 122 pp.

13. Karte "Pazemes ūdeņu aizsardzība un geologiskā riska teritorijas". Krāj.: Geologisiskas informācijas sagatavošana valsts nacionālā plānojuma vajadzībām. 2.sēj. Valsts Ģeologiijas dienests, Rīga. 1998, 35 lpp.

14. Nikuļins, V. Latvijas vēsturisko zemestrīču seismotehniskā pozīija. Latvijas geologiijas vēstis, 1996.Nr.1. Rīga, Valsts ǵeologijas dienests, 31.-36.lpp.

15. Nikulins, V. Latvijas seismotektoniskie apstākḷi un seismiskā bīstamība. Promocijas darba kopsavilkums. LU Akadēmiskais apgāds, Rīga, 2007, 106 lpp.

Anotācija. Rakstā apskatīti galvenie ǵeoloğiski geomorfologiskā riska ('̇eologiskā riska) novērtēšanas aspekti, izklāstot GIS bāzētu metodologiju šāda veida vides apdraudējuma identificēšanai un analīzei Daugavpils un Ilūkstes novados. Raksts ieklauj, pirmkārt, pārskatu par geologiskā riska faktorus raksturojošās informācijas un datu pieejamību un situāciju šajā jomāa; otrkārt, geomātikas metožu aprakstu riska faktoru tematisko slānnu ieguvei un pañēmienus šo datu apkopošanai un apstrādei; un, treškārt, summārā geologisiskā riska novērtējumu un analīzi. Šāda kompleksa GIS bäzēta pieeja geologiskā riska izpētē lìdz šim nav tikusi izmantota nedz pètījumu teritorijāa, nedz arī Latvijāa. Iegūtie rezultāti vienlaicīgi ar̄̄ ļauj izcelt tos apgabalus, kuri ir paklauti geoloğiskajam riskam Daugavpils un Ilūkstes novados, tādējādi nodrošinot nozīmīgu informāciju šo pašvaldību teritoriju plānošanas vajadzībām. 